\title{
FAKTOR-FAKTOR YANG MEMPENGARUHI DISIPLIN KERJA PADA PT. ARTA SEDANA SINGARAJA
}

\author{
Ketut Hendra ${ }^{1}$, Lulup Endah Tri Palupi ${ }^{2}$, Nyoman Sujana ${ }^{3}$ \\ Jurusan Pendidikan Ekonomi \\ Universitas Pendidikan Ganesha \\ Singaraja, Indonesia

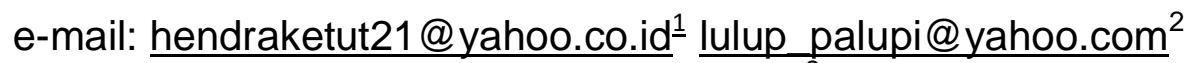 \\ sujanatbn@yahoo.com ${ }^{3}$
}

\begin{abstract}
Abstrak
Penelitian ini bertujuan untuk mengetahui faktor-faktor yang mempengaruhi disiplin kerja karyawan seerta yang paling dominan mempengaruhi disiplin kerja karyawan pada PT. Arta Sedana Singaraja. Jenis penelitian ini merupakan penelitian faktorial dengan sampel jenuh. Populasi dari penelitian ini adalah adalah seluruh karyawan masing-masing divisi yang ada pada PT Arta Sedana Singaraja dengan jumlah keseluruhan 45 responden. Metode pengumpulan data yang digunakan adalah kuesioner, data yang diperoleh kemudian dianalisis dengan menggunakan analisis faktor melalui program Statitical Program Social Scene (SPSS) 16.0 for windows. Hasil penelitian menunjukan bahwa terdapat lima faktor yang mempengaruhi disiplin kerja pada PT. Arta Sedana Singaraja, yaitu faktor motivasi, faktor pendidikan dan pelatihan, faktor kepemimpinan, faktor kesejahteraan, serta faktor penegakan disiplin melalui hukum. Besarnya variance explained masing-masing faktor secara berturut-turut yaitu faktor motivasi sebesar $54,877 \%$, faktor pendidikan dan pelatihan sebesar $20,074 \%$, faktor kepemimpinan sebesar $11,994 \%$, faktor kesejahteraan sebesar $8,884 \%$, faktor penegakan disiplin melalui hukum sebesar $4,171 \%$. Faktor motivasi menjadi fakor yang paling dominan karena memiliki nilai varimax rotation sebesar $54,877 \%$, artinya total nilai varimax rotation dari faktor motivasi mampu menjelaskan disiplin kerja karyawan sebesar $54,877 \%$.
\end{abstract}

Kata kunci: disiplin kerja, karyawan.

\begin{abstract}
This research aims to know factors which affect the performance discipline of employee, and the most dominant factor which affects performance discipline of employee at PT. Arta Sedana Singaraja. A kind of this research is factorial research with full sample. The population of this research is all of employees each division on PT. Arta Sedana Singaraja which totaled 45 person. Data collection methods using a questionnaire and analyzed with factorial analysis by Statitical Program Social Scene (SPSS) 16.0 for windows program. The result of this research is showed, there are five factors which affect the performance discipline of employee at PT. Arta Sedana Singaraja, that is motivation, education and trainings, leadership, prosperity, and enforcement of discipline by the law. The size of variance explained factor in order, specifically motivation is as much as $54,877 \%$, education and trainings is as much as $20,074 \%$, the leadership is as much as $11,994 \%$, the prosperity is as much as $8,884 \%$ and the enforcement of discipline by the law is as much as $4,171 \%$. The most dominant factor which affects affect the performance discipline of employee at PT. Arta Sedana Singaraja is the motivation which has the varimax rotation as much as $54,877 \%$, it means the total value of varimax rotation of the motivation is able to explain the performance discipline of employee at PT. Arta Sedana Singaraja.
\end{abstract}

Keyword: discipline of work, employee. 


\section{PENDAHULUAN}

Sedangkan menurut Dessler (dalam Nasution, 2009) manajemen sumber daya manusia merupakan suatu kebijakan dan cara-cara yang dipraktekan dan berhubungan dengan pemberdayaan manusia atau aspek-aspek sumber daya manusia dari sebuah posisi manajemen termasuk perekrutan, seleksi, pelatihan, penghargaan dan penilaian. Lain pula yang dikemukakan oleh Bangun (2012 : 6) "manajemen sumber daya manusia berkaitan dengan pengelolaan manusia melalui aktivitas-aktivitas organisasi dan fungsi-fungsi lain pada operasionalnya". Sementara menurut Kinggundu (dalam Rosidah, 2003 : 11) "MSDM adalah pengembangan dan pemanfaatan pegawai dalam rangka tercapainya tujuan dan sasaran individu, organisasi, masyarakat, bangsa dan internasional yang efektif". Pendapat lainnya dikemukakan oleh Simamora (dalam Sutrisno, 2012 : 5) "manajemen sumber daya manusia merupakan pendayagunaan pengembangan, penilaian, pemberian balas jasa dan pengelolaan individu anggota organisasi atau kelompok pekerja".

Salah satu syarat untuk mencapai tujuan perusahaan adalah diperlukan Sumber Daya Manusia (SDM) yang memiliki disiplin kerja yang tinggi. Sebab jika karyawan tidak disiplin dalam melaksanakan pekerjaannya maka akan ada kemungkinan terjadi kelalaian dalam melaksanakan tugasnya. Menurut kamus Besar Bahasa Indonesia (KBBI) disiplin adalah "ketaatan atau kepatuhan terhadap tata tertib yang berlaku (di sekolah, kemiliteran dan lain sebagainya)". Menurut Hasibuan (2012 : 193) "kedisiplinan adalah kesadaran dan kesediaan seseorang menaati peraturan perusahaan dan normanorma yang berlaku".

$$
\text { Sementara }
$$

Lateiner

mengartikan bahwa disiplin sebagai suatu kekuatan yang berkembang di dalam tubuh karyawan dan menyebabkan karyawan dapat menyesuaikan diri dengan sukarela pada keputusan, peraturan, dan nilai-nilai tinggi dari pekerjaan dan perilaku. Lain halnya seperti yang dikemukakan oleh Rosidah (2003 : 236) "disiplin adalah prosedur yang mengkoreksi atau menghukum bawahan karena melanggar peraturan atau prosedur".

Menurut Tery (dalam Sutrisno, 2012) disiplin kerja merupakan alat penggerak karyawan. Agar tiap pekerjaan dapat berjalan dengan lancar, maka harus di usahakan agar ada disiplin yang baik. Tery kurang setuju jika disiplin di hubungkan dengan hal-hal yang kurang menyenangkan (hukuman), karena hukuman merupakan alat paling akhir untuk menegakkan disiplin.

Bagi Beach (dalam Siagian, 2002), disiplin mempunyai dua arti. Arti yang pertama, melibatkan belajar atau mencetak perilaku dengan menerapkan imbalan atau hukuman. Arti kedua lebih sempit lagi, yaitu disiplin hanya berhubungan dengan tiindakan hukuman terhadap pelaku kesalahan. Siswanto ( dalam rosidah 2003) "disiplin adalah suatu sikap menghormati, menghargai, patuh dan taat terhadap peraturan-peraturan yang berlaku, baik yang tertulis maupun tidak tertulis serta sanggup menjalankan untuk menerima sanksi-sanksi apabila ia melanggar tugas dan wewenang yang diberikan".

Kedisiplinan sangat bermanfaat untuk meningkatkan keterampilan dan kemampuan para karyawan guna menunjang perubahan sikap para karyawan yang berdasarkan motivasi untuk berprestasi di dalam suatu organisasi. Kedisiplinan juga merupakan faktor utama untuk meningkatkan produktivitas kerja karyawan dalam organisasi disamping faktor-faktor atau sumber daya yang lain. Menurut Hasibuan (2012) disiplin yang baik mencerminkam besarnya rasa tanggungjawab seseorang terhadap tugastugas yang diberikan kepadanya. Ardana (2012) secara umum menyatakan tujuan utama pembinaan disiplin kerja adalah untuk menjaga kontinuitas perusahaan sebagai motif dari perusahaan baik hari ini ataupun hari esok. secara khusus menyatakan tujuan utama pembinaan disiplin kerja yang pertama adalah agar para tenaga kerja menepati segala peraturan-peraturan dan kebijakan ketenagakerjaan maupun peraturan perusahaan yang berlaku, kedua dapat melaksanakan pekerjaan dengan baik serta mampu memberikan servis yang maksimal kepada pihak stakeholder, ketiga dapat 
menggunakan sarana, prasarana, barang dan jasa secara baik, keempat dapat bertindak sesuai dengan norma-norma yang berlaku, dan yang ke lima adalah follow up dari hal-hal di atas para pekerja mampu menghasilkan produktivitas yang tinggi.

Sementara menurut Tohardi (dalam Sutrisno, 2012) tujuan disiplin adalah untuk mencapai tujuan organisasi atau perusahaan lebih jauh, guna mejanga efisiensi dengan mencegah dan mengoreksi tindakan-tindakan individu dalam itikad tidak baiknya terhadap kelompok, selain itu disiplin berusaha untuk melindungi perilaku yang baik dengan menetapkan respons yang di kehendaki bagi setiap karyawan.

Sinambela (2012) mengemukakan bahwa kegunaan disiplin dalam organisasi dapat diperlihatkan dalam empat perspektif. Perspektif tersebut yang pertama adalah perspektif retribusi dimana perspektif retribusi disiplin kerja digunakan untuk menghukum para pelanggar aturan. Pendisiplinan dilakukan secara profesional dengan sasarannya.

Yang kedua adalah perspektif korektif dimana dalam perspektif korektif disiplin kerja berguna untuk mengoreksi tindakan karyawan atau pegawai yang tidak tepat. Ketiga adalah perspektif sanksi, yang diberikan untuk memberikan kesadaran pada perilaku yang salah dan memberikan efek yang positif untuk mencapai tujuan perusahaan atau organisasi. Serta yang keempat adalah perspektif hak-hak individu dimana disiplin kerja berguna untuk melindungi hak-hak untuk memastikan bahwa manfaat penegakan disiplin melebihi kosekuensi-konsekuensi negatif yang harus ditanggung para karyawan. Perspektif tersebut dapat digunakan sebagai pengendalikan kegiatan karywan.

Ada beberapa faktor yang mempengaruhi kedisiplinan karyawan. Menurut Soejono (dalam Siagan, 2009) faktor yang dapat mempengaruhi disiplin kerja yang pertama adalah ketepatan waktu, dimana dalam setiap kegiatan perusahaan para karyawan di tuntut untuk menyelesaikan pekerjaannya tepat waktu. Para pegawai datang ke kantor tepat waktu, tertib dan teratur, dengan begitu dapat dikatakan disiplin kerja baik. Kedua adalah menggunakan peralatan kantor dengan baik, hal ini menunjukan sikap hati-hati dalam menggunakan peralatan kantor, dapat menunjukkan bahwa seseorang memiliki disiplin kerja yang baik, sehingga peralatan kantor dapat terhindar dari kerusakan. Ketiga adalah tanggung jawab dimana pegawai yang senantiasa menyelesaikan tugas yang dibebankan kepadanya sesuai dengan prosedur dan bertanggung jawab atas hasil kerja, dapat pula dikatakan memiliki disiplin yang baik. Keempat yaitu ketaatan terhadap aturan kantor dimagsudkan kepada pegawai memakai seragam kantor, menggunakan kartu tanda name tag (pengenal/identitas), membuat ijin bila tidak masuk kantor, mengerjakan tugas sesuai prosedur tanpa merugikan perusahaan adalah merupakan cerminan dari disiplin yang tinggi.

2009) $\begin{gathered}\text { Singodimedjo (dalam Sutrisno, } \\ \text { menyebutkan faktor yang }\end{gathered}$ mempengaruhi disiplin pegawai yang pertama adalah besar kecilnya pemberian kompensasi dimana besar kecilnya kompensasi dapat mempengaruhi tegaknya disiplin. Para karyawan akan mematuhi segala peraturan yang berlaku, bila ia merasa mendapat jaminan balas jasa yang setimpal dengan jerih payahnya yang telah dikontribusikan bagi perusahaan. Bila ia menerima kompensasi yang memadai, mereka akan dapat bekerja tenang dan tekun, serta selalu berusaha bekerja dengan sebaik-baiknya. Akan tetapi, bila ia merasa kompensasi yang diterimanya jauh dari memadai, maka ia akan berpikir mendua, dan berusaha untuk mencari tambahan penghasilan lain di luar. Dalam praktik lapangan, memang dengan pemberian kompensasi yang mencukupi, sedikit banyak akan membantu karyawan untuk bekerja tenang, karena dengan menerima kompensasi yang wajar kebutuhan primer mereka akan dapat terpenuhi. Yang kedua adalah ada tidaknya keteladanan pimpinan dalam perusahaan, keteladanan pimpinan sangat penting sekali, karena dalam lingkungan perusahaan, semua karyawan akan selalu memperhatikan bagaimana pimpinan dapat menegakkan disiplin 
dirinya dari ucapan, perbuatan dan sikap yang dapat merugikan aturan disiplin yang sudah ditetapkan. Peranan keteladanan pimpinan sangat berpengaruh besar dalam perusahaan, bahkan sangat dominan dibandingkan dengan semua faktor yang mempengaruhi disiplin dalam perusahaan, karena pimpinan dalam suatu perusahaan masih menjadi panutan para karyawan. Para bawahan akan selalu meniru yang dilihatnya setiap hari. Apa pun yang dibuat pimpinannya. Oleh sebab itu, bila seseorang pemimpin menginginkan tegaknya disiplin dalam perusahaan, maka ia harus lebih dulu mempraktikkan, supaya dapat diikuti dengan baik oleh para karyawan lainnya. Ketiga yaitu ada tidaknya aturan pasti yang dapat dijadikan pegangan, dimana pembinaan disiplin tidak akan dapat terlaksana dalam perusahaan, bila tidak ada aturan tertulis yang pasti untuk dapat dijadikan pegangan bersama. Disiplin tidak mungkin ditegakkan bila peraturan yang dibuat hanya berdasarkan instruksi lisan yang dapat berubah-ubah sesuai dengan kondisi dan situasi. Keempat adalah keberanian pimpinan dalam mengambil tindakan, bila ada seorang karyawan yang melanggar disiplin, maka perlu ada keberanian pimpinan untuk mengambil tindakan yang sesuai dengan tingkat pelanggaran yang dibuatnya. Dengan adanya tindakan terhadap pelanggar disiplin, sesuai dengan sanksi yang ada, maka semua karyawan akan merasa terlindungi, dan dalam hatinya berjanji tidak akan berbuat hal yang serupa. Dalam situasi demikian, maka semua karyawan akan benarbenar terhindar dari sikap sembrono, asal jadi seenaknya sendiri dalam perusahaan. Sebaliknya, bila pimpinan tidak berani mengambil tindakan, walaupun sudah terang-terangan karyawan tersebut melanggar disiplin, tetapi tidak ditegur/dihukum, maka akan berpengaruh kepada suasana kerja dalam perusahaan. Kelima adalah ada tidaknya pengawasan pimpinan, dalam setiap kegiatan yang dilakukan oleh perusahaan oleh perusahaan perlu ada pengawasan, yang akan mengarahkan para karyawan agar dapat melaksanakan pekerjaan dengan tepat dan sesuai dengan yang telah ditetapkan. Namun sudah menjadi tabiat manusia pula bahwa mereka selalu ingin bebas, tanpa terikat atau diikat oleh peraturan apapun juga. Dengan adanya pengawasan seperti demikian, maka sedikit banyak para karyawan akan terbiasa melaksanakan disiplin kerja. Mungkin untuk sebagian karyawan yang sudah menyadari arti disiplin, pengawasan seperti ini tidak perlu, tetapi bagi karyawan lainnya, tegaknya disiplin masih perlu agak dipaksanakan, agar mereka tidak berbuat semaunya dalam perusahaan. Keenam yaitu ada tidaknya perhatian kepada para karyawan, dimana karyawan adalah manusia yang mempunyai perbedaan karakter antara yang satu dengan yang lain. Seorang karyawan tidak hanya puas dengan penerimaan kompensasi yang tinggi, pekerjaan yang menantang, tetapi juga mereka masih membutuhkan perhatian yang besar dari pimpinannya sendiri. Keluhan dan kesulitan mereka ingin didengar, dan dicarikan jalan keluarnya, dan sebagainya. Pimpinan yang berhasil memberi perhatian yang besar kepada para karyawan akan dapat menciptakan disiplin kerja yang baik. Karena ia bukan hanya dekat dalam arti jarak fisik, tetapi juga mempunyai jarak dekat dalam artian jarak batin. Pimpinan demikian akan selalu dihormati dan dihargai oleh para karyawan, sehingga akan berpengaruh besar kepada prestasi, semangat kerja dan moral kerja karyawan. Ketujuh adalah kebiasaan-kebiasaan yang mendukung tegaknya disiplin, Kebiasaankebiasaan positif itu, seperti mengucapkan salam dan berjabat tangan apabila bertemu, saling menghargai antar sesama rekan, saling memperhatikan antar sesama rekan, memberitahu saat meninggalkan tempat kerja kepada rekan. Menurut Martoyo (2000), yang pertama motivasi adalah tindakan untuk mempengaruhi orang lain agar bertindak teratur, kedua pendidikan dan latihan adalah suatu proses pembinaan yang membantu pegawai dalam memahami suatu pengetahuan praktis guna meningkatkan keterampilandalam penggunaan alat maupun prosedur kerja, ketiga kepemimmpinan adalah sikap pemimpin mampu mempengaruhi perilaku 
bawahannya, agar mau bekerjasama dan bekerja secara produktif untuk mencapai tujuan organisasi, keempat kesejahteraan adalah balas jasa pelengkap (material dan non material) yang diberikan untuk mempertahankan dan memperbaiki kondisi fisik dan mental pegawai agar produktivtas kerjanya meningkat, dan yang kelima adalah penegakan disiplin melalui hokum, adalah tindakan dari perusahaan untuk mengatur tingkah laku karyawan dengan menegakan aturan dan sanksi yang jelas mengatur setiap kegiatan karyawan.

PT. Arta Sedana Singaraja bergerak dibidang distributor makanan, minuman, obat-obatan dan alat laboratorium, yang berkedudukan di Jalan Pulau Komodo I No. 9 Lingkungan Banyuning Tengah, Kelurahan Banyuning, Kecamatan Buleleng, Kabupaten Buleleng. PT. Arta Sedana Singaraja didirikan pada tanggal 28 Oktober 2015, dengan Surat Izin Usaha Perdagangan (SIUP) nomor 50312/1140/SIUP/BPPT/2015. PT. Arta Sedana Singaraja memiliki visi yaitu menjadi perusahaan distributor barang dan jasa (pembangunan, makanan dan minuman, obat-obatan, dan alat laboratorium) terbesar di Kabupaten Buleleng. Dalam menjalankan usahanya PT. Arta Sedana Singaraja mengedepankan disiplin kerja kepada para karyawannya dalam bentuk peraturan dan saksi. Untuk membentuk SDM yang disiplin dan lebih berkualitas maka dilakukanlah penegakan peraturan, yang dinyatakan dalam Peraturan Perusahaan PT. Arta Sedana Singaraja.

Untuk membentuk SDM yang disiplin dan lebih berkualitas maka dilakukanlah penegakan peraturan, yang dinyatakan dalam Peraturan Perusahaan PT. Arta Sedana Singaraja pada Bab III tentang Tindakan Disiplin dan Surat Peringatan. Pembinaa dan peringatan lisan diberikan kepada karyawan tertuang pada pasal 3.2. Pasal 3.3 menjelaskan mengenai pemberian Surat Peringatan I jika karyawan terlambat 4 kali. Pasal 3.4 menjelaskan mengenai pemberian Surat Peringatan II jika karyawan terlambat 5 kali pada bulan sama. Sedangkan dilihat pada Pasal 3.5 menjelaskan mengenai pemberian Surat Peringatan III jika karyawan terlambat 6 kali pada bulan yang sama.

Tindakan kedisiplinan tersebut berupa Peringatan lisan jika pelanggaran yang dilakukan sampai 5 kali, surat peringatan (SP) 1 jika pelanggaran dilakukan 10 kali, SP2 jika pelanggaran dilakukan sampai dengan 15 kali, SP3 jika pelanggaran dilakukan sampai dengan 20 kali, skorsing jika pelanggaran dilakukan sampai lebih dari 20 kali dan pemberhentian kerja bila sudah melakukan pelanggaran berat. Peraturan ini dibuat untuk meningkatkan tingkat disiplin serta menciptakan dan mempertahankan rasa hormat dan saling percaya diantara supervisior dan bawahannya.

Namun kenyataan yang terjadi pada perusahaan masih saja ada karyawan yang masih melakukan pelanggaran. Pelanggaran disiplin yang terjadi per Desember 2016 dilakukan oleh 10 orang dari 45 karyawan, hanya karyawan bernama Riska Yuni Setiarini dengan kategori pelanggaran yang dapat ditoleransi yakni sebanyak 3 kali pelanggaran. Meskipun tergolong rendah, sanksi tetap diberikan yaitu berupa teguran lisan. Karyawan yang mendapat SP2 yakni Made Yuli Astiti sebanyak 12 kali, Komang Mustika dengan pelanggaran sebanyak 14 kali, Ida Ayu Karini dan Putu Mega Oktaviani masing-masing sebanyak 15 kali. Dan pelanggaran tertinggi dilakukan oleh Gede Widiarsa yakni sebanyak 18 kali, Gede Arsana 17 kali, Ketut Arta, Kadek Restika dan Komang Hendra Darmawan masing-masing melakukan pelanggaran sebanyak 16 kali, dengan sanksi berupa Surat Peringatan (SP) 3. Berdasarkan data tersebut jelas terlihat bahwa walaupun sudah ada peraturan dan sanksi kerja, tetapi masih saja ada karyawan yang melanggar peraturan dengan pelanggaran tergolong tinggi. Sehingga dapat dikatakan sangat jauh dari harapan perusahaan yang tertuang pada Bab III tentang Tindakan Disiplin dan Surat Peringatan yang menyatakan, tindakan kedisiplinan dimaksudkan untuk membentuk SDM yang lebih berkualitas. Hal ini sangat bertolak belakang dengan pengertian kedisiplinan itu tersendiri yaitu suatu sikap 
ketersediaan dan sukarela seseorang untuk mematuhi dan menaati normanorma yang berlaku pada lingkungan sekitarnya.

Berdasarkan perumusan masalah tersebut, maka dapat dirumuskan tujuan penelitian adalah yang pertama untuk mengetahui faktor-faktor yang mempengaruhi disiplin kerja karyawan pada PT. Arta Sedana Singaraja, dan yang kedua untuk mengetahui faktor yang paling dominan mempengaruhi disiplin kerja karyawan pada PT. Arta Sedana Singaraja.

\section{METODE}

Penelitian ini menggunakan jenis rancangan penelitian faktorial. Penelitian ini dilakukan untuk mengetahui faktorfaktor yang mempengaruhi disiplin kerja karyawan pada PT. Arta Sedana Singaraja, dan untuk mengetahui faktor yang paling dominan mempengaruhi disiplin kerja karyawan pada PT. Arta Sedana Singaraja. Data dalam penelitian ini akan dianalisis menggunakan analisis faktor, dalam penelitian analisis fator hubungan antar variabel tersebut saling ketergantungan (interdependence) sehingga tidak ada pembagian variabel bebas dan variabel terikat.

Adapun yang menjadi subjek dalam penelitian ini adalah seluruh karyawan masing-masing divisi yang ada pada PT Arta Sedana Singaraja yang berjumlah 45 orang. Sedangkan objek penelitian ini adalah disiplin kerja yang terjadi per Desember 2016.

Jenis data yang digunakan dalam penelitian ini adalah data kuantitatif. Data kuantitatif adalah data yang dapat dinyatakan dalam bentuk angka-angka berupa skor jawaban yang diperoleh dari responden yaitu seluruh karyawan mengenai faktor yang paling dominan mempengaruhi disiplin kerja karyawan pada PT. Arta Sedana Singaraja.

Ditinjau dari sumbernya, data yang digunakan dalam kegiatan penelitian ini adalah data primer, yang berupa skor hasil kuisioner yang diperoleh dari jawaban responden mengenai disiplin kerja karyawan, dan data sekunder yang diperoleh dari dokumen-dokumen yang ada dalam perusahaan. Data ini berupa gambaran umum perusahaan

Pengumpulan data dilakukan dengan metode kuesioner atau angket. Kuesioner dalam penelitian ini disebar kepada 45 responden yang merupakan karyawan PT Arta Sedana Singaraja. Sesuai dengan rumusan masalah, jenis data, serta tujuan penelitian maka metode analisis data yang digunakan dalam penelitian ini adalah model analisis faktor. Metode analisis faktor merupakan metode yang digunakan untuk mereduksi data atau meringkas dari variabel yang banyak menjadi variabel yang lebih sedikit, dengan menggunakan SPSS 16.0 for windows (Zuriah, 2006).

Langkah-langkah analisis faktor yaitu yang pertama membuat matrik, dimana semua data yang masuk dan diolah akan menghasilkan matrik korelasi. Matrik korelasi dapat mengidentifikasi variabel-variabel tertentu yang tidak mempunyai korelasi dengan variabel yang lain, sehingga dapat dikeluarkan dari analisis. Pengujian ketepatan model analisis faktor menggunakan Barlett's test of Sphericity untuk menguji variabelvariabel dalam sampel berkorelasi, dan menunjukan apakah hubungan antar variabel signifikan atau tidak. Statistik lain yang dapat digunakan untuk mengukur kelayakan sampel Kaiser Meyer Olikin (KMO). Analisis faktor dianggap layak jika $\mathrm{KMO}$ nilainya minimal 0,5 . Besaran ini digunakan untuk mengukur korelasi antar variabel dengan kreteria Measure of Sampling Adequacy (MSA) >0,5. Yang kedua yaitu menentukan jumlah faktor, dimana dimensi atau faktor disusun kembali berdasarkan pada korelasi hasil langkah pada butir dua untuk menentukan faktor yang diperlukan untuk mewakili data. Untuk menentukan beberapa faktor yang dapat diterima data secara empirik dapat dilakukan berdasarkan besarnya eigenvalue setiap faktor yang muncul. Semakin besar eigenvalue setiap faktor, semakin representattif faktor tersebut untuk mewakii sekelompok variabel. Faktor-faktor ini yang dipilih adalah faktor yang mempunyai eigenvalue sama dengan atau lebih dari satu. Yang ketiga dilakukannya rotasi faktor, dimana hasil 
penyederhanaan faktor dalam matrix faktor memperlihatkan hubungan antar faktor dengan faktor individu, tetapi dalam faktorfaktor tersebut terdapat banyak variabel yang berkorelasi sehingga sulit di interprestasikan. Dengan menggunakan rotasi faktor matrik, matrik faktor di tranformasikan kedalam matrik yang sederhana sehingga mudah untuk di interprestasikan. Dalam perilaku ini digunakan rotasi varimax. Yang keempat dilakukannya interprestasi faktor dengan mengelompokan variabel yang mempunyai faktor loading tinggi kedalam faktor tersebut. Untuk interprestasikan hasil peelitian ini, faktor loading 0,5 . Variabel yang memiliki loading $<0,5$ dikeluarkan dari model. Yang ke lima menentukan ketepatan model apakah mampu menjelaskan dengan baik. Fenomena yang perlu diuji dengan teknik Principal Component Analysis (PCA) yaitu dengan melihat jumlah resudial antara korelasi yang diamati dengan korelasi yang direproduksi. Dalam penelitian ini, untuk mempermudah proses perhitungan dan untuk mendapatkan hasil perhitungan yang akurat dalam analisis data, peneliti menggunakan alat hitung berupa program SPSS 16.0 for windows.

\section{HASIL DAN PEMBAHASAN Hasil}

Data yang berhasil dikumpulkan dari kuesioner yang disebarkan dan setelah diolah dengan SPSS 16.0 for Windows menunjukkan faktor-faktor yang mempengaruhi disiplin kerja pada PT. Arta Sedana Singaraja dapat dijelaskan oleh persentase dari masing-masing faktor. Nilai total Variance Explained digunakan untuk mengetahui persentase dari lima faktor yang dianalisis. Hasil analisis faktor melalui SPSS menunjukkan presentase dari masing-masing faktor yang dapat dilihat pada Tabel 1.

TABEL.1 Total Variance Explained

\begin{tabular}{|c|c|c|c|c|c|c|c|c|c|}
\hline \multirow{2}{*}{$\begin{array}{l}\text { Comp } \\
\text { onent }\end{array}$} & \multicolumn{3}{|c|}{ Initial Eigenvalues } & \multicolumn{3}{|c|}{$\begin{array}{l}\text { Extraction Sums of } \\
\text { Squared Loadings }\end{array}$} & \multicolumn{3}{|c|}{$\begin{array}{c}\text { Rotation Sums of Squared } \\
\text { Loadings }\end{array}$} \\
\hline & Total & $\begin{array}{c}\% \text { of } \\
\text { Variance }\end{array}$ & $\begin{array}{l}\text { Cumulati } \\
\text { ve } \%\end{array}$ & Total & $\begin{array}{c}\text { \% of } \\
\text { Variance }\end{array}$ & $\begin{array}{l}\text { Cumulat } \\
\text { ive } \%\end{array}$ & Total & $\begin{array}{c}\% \text { of } \\
\text { Variance }\end{array}$ & $\begin{array}{l}\text { Cumulati } \\
\text { ve } \%\end{array}$ \\
\hline 1 & 2.744 & 54.877 & 54.877 & 2.744 & 54.877 & 54.877 & 1.972 & 39.434 & 39.434 \\
\hline 2 & 1.004 & 20.074 & 74.951 & 1.004 & 20.074 & 74.951 & 1.776 & 35.517 & 74.951 \\
\hline 3 & .600 & 11.994 & 86.945 & & & & & & \\
\hline 4 & .444 & 8.884 & 95.829 & & & & & & \\
\hline 5 & .209 & 4.171 & 100.000 & & & & & & \\
\hline
\end{tabular}

bahwa motivasi memiliki eigenvalue sebesar 2,744 dengan nilai varian sebesar $54,877 \%$, faktor pendidikan dan pelatihan memiliki eigenvalue sebesar 1,004 dengan nilai varian sebesar $20,074 \%$, faktor kepemimpinan memiliki eigenvalue sebesar 0,600 dengan nilai varian $11,994 \%$, faktor kesejahteraan memiliki eigenvalue sebesar 0,444 dengan nilai varian $8,884 \%$, faktor penegakan disiplin melalui hukum memiliki eigenvalue sebesar 0,209 dengan nilai varian sebesar $4,171 \%$.

Untuk menjelaskan disiplin kerja pada PT. Arta Sedana Singaraja, hal yang dapat dilakukan yaitu dengan melakukan ekstraksi faktor. Ekstraksi faktor dapat dijelaskan dengan melihat hasil dari total persentase dari masing-masing faktor utama. Faktor-faktor utama tersebut adalah faktor motivasi serta faktor pendidikan dan latihan yang masing-masing memiliki nilai parameter eigenvalue $>1$. Untuk mengetahui distribusi dimensi-dimensi yang belum dirotasi kedalam faktor yang telah terbentuk maka dapat dilihat pada output SPSS 16.0 (Rotated Component Matrix). Faktor yang mampu menjelaskan disiplin kerja pada PT. Arta Sedana Singaraja, dapat dilihat pada Tabel 2. 
Tabel 2. Faktor yang Menjelaskan Disiplin Kerja pada PT. Arta Sedana Singaraja

\begin{tabular}{|c|c|c|c|}
\hline Faktor & Eigenvalup744 & Varianced Explaine $\$(\$, / 977$ & Faktor Bo\&ding \\
\hline Motivasi & 1.004 & 20.074 & .856 \\
\hline Pendidikan dan Latihan & 0.600 & 11.994 & .860 \\
\hline $\begin{array}{l}\text { Kepemimpinan } \\
\text { Kesejahteraan }\end{array}$ & 0.444 & 8.884 & .720 \\
\hline $\begin{array}{l}\text { Penegakan Disiplin } \\
\text { Melalui Hukum }\end{array}$ & 0.209 & 4.171 & 868 \\
\hline
\end{tabular}

Berdasarkan dari Tabel 2 di atas, dapat dijelaskan bahwa faktor yang memiliki eigenvalue $>1$ adalah fakor motivasi serta pendidikan dan latihan, total nilai variance explained dari kedua faktor keseluruhan mampu menjelaskan sebesar $74,951 \%$, dengan demikian $74,951 \%$ dari seluruh faktor yang ada, dapat dijelaskan oleh kedua faktor yang terbentuk. Sementara itu motivasi memiliki variance explained $54,877 \%$, artinya bahwa motivasi mampu mempengaruhi disiplin kerja karyawan sebesar $54,877 \%$. Selain itu pendidikan dan pelatihan memiliki variance explained $20,074 \%$, artinya pendidikan dan latihan mempengaruhi disiplin kerja karyawan sebesar $20,074 \%$.

Menentukan nama faktor yang telah berbentuk berisi subjektif. Kadang kala variabel yang memiliki nilai faktor loading tertinggi biasanya digunakan untuk memberi nama faktor pada dimensi yang ada. Untuk melihat nilai faktor loading dapat dilihat pada Tabel 3 sebagai berikut.

Tabel 3. Rotated Component Matrix

\begin{tabular}{|c|c|}
\hline & Component \\
\hline & 2 \\
\hline Motivasi & 035 \\
\hline Pendidikan dan Latihan & ,856 \\
\hline Kepemimpinan & 226 \\
\hline Kesejahteraan & ,487 \\
\hline Penegakan Disiplin Melalui Hukum & 208 \\
\hline $\begin{array}{l}\text { Bedasarkan Tabel } 3 \text { di atas, faktor } \\
\text { ang mempengaruhi disiplin kerja karyawan } \\
\text { apat dikelompokkan menjadi } 2 \text { (dua) } \\
\text { ktor. Masing-masing kelompok faktor } \\
\text { rsebut memiliki faktor loading tertinggi di } \\
\text { tiap komponen yaitu faktor satu terbentuk } \\
\text { ari faktor Faktor } 1 \text { (satu) terbentuk dari } \\
\text { ktor motivasi dengan faktor loading } \\
\text { besar } 0,808 \text {, faktor kepemimpinan } \\
\text { engan faktor loading sebesar 0,860, dan } \\
\text { ktor kesejahteraan dengan faktor loading } \\
\text { besar 0,720. Faktor } 2 \text { (dua) terbentuk } \\
\text { ari faktor pendidikan dan pelatihan dengan } \\
\text { ktor loading sebesar } 0,856 \text {, faktor }\end{array}$ & $\begin{array}{l}\text { penegakan disiplin melalui hukum dengan } \\
\text { faktor loading } 0,868 \text {. } \\
\text { Selanjutnya untuk menentukan faktor } \\
\text { yang paling dominan mempengaruhi disiplin } \\
\text { kerja pada PT. Arta Sedana Singaraja, } \\
\text { digunakan parameter koefesien varimax } \\
\text { rotation dengan nilai yang mendekati } 1 \text { atau } \\
\text { mendekati }-1 \text {. Nilai yang mendekati } 1 \\
\text { diawali oleh nilai } 0,50 \text { sedangkan nilai yang } \\
\text { mendekati -1 diawali oleh }-0,50 \text {. Untuk } \\
\text { mengetahui secara lebih rinci hasil } \\
\text { ringkasan rotasi dari matriks faktor memuat } \\
\text { nilai varimax rotation, dapat dilihat pada } \\
\text { tabel }\end{array}$ \\
\hline
\end{tabular}


Tabel 4. Matriks Rotasi Hasil Anallisis Faktor

Dimensi atau faktor keputusan membeli

Motivasi

Pendidikan dan Latihan

Berdasarkan tabel 4, maka faktor yang paling dominan mempengaruhi disiplin kerja pada PT. Arta Sedana Singaraja adalah faktor motivasi dengan nilai varimax rotation $58,877 \%$. Hal ini berarti kejelasan dari dimensi atau faktor disiplin kerja adalah motivasi yang paling mendominasi, yaitu sebesar $58,877 \%$.

\section{Pembahasan}

Disiplin kerja pada karyawan PT. Arta Sedana Singaraja dipengaruhi oleh faktor motivasi, pendidikan dan latihan, kesejahteraan, kepemimpinan, serta penegakan disiplin melalui hukum, sesuai dengan pendapat Martoyo (2000) menyatakan bahwa faktor yang mempengaruhi disiplin kerja adalah motivasi, pendidikan dan latihan, kesejahteraan, kepemimpinan, serta penegakan disiplin melalui hukum. Untuk menjelaskan yang mempengaruhi disiplin kerja pada karyawan PT. Arta Sedana Singaraja, dapat dilihat dari faktor-faktor yang memiliki eigenvalue $>1$, yaitu faktor motivasi serta faktor pendidikan dan latihan.

Faktor motivasi serta faktor pendidikan dan latihan merupakan faktor utama mempengaruhi disiplin kerja pada karyawan PT. Arta Sedana Singaraja. Faktor motivasi adalah faktor yang paling dominan mempengaruhi disiplin kerja pada karyawan PT. Arta Sedana Singaraja karena motivasi adalah faktor utama yang membuat karyawan semangat dan terpacu untuk disiplin dalam bekerja. Motivasi pada dasarnya adalah kondisi mental yang mendorong dilakukannya suatu tindakan dan memberikan kekuatan yang mengarah kepada pencapaian kebutuhan, memberikan kepuasan atau mengurangi ketidakseimbangan. Menurut Hasibuan (2012) promosi, kondisi lingkungan sosial dan lingkungan fisik di tempat kerja dapat menjadi motivasi bagi para karyawan agar mau bekerja giat yang mengarah pada

\author{
(1)
} Varimax Rotation (\%)

(2)

\subsection{7}

- $\quad 20,074$

pencapaian kebutuhan, sehingga dapat melakukan tugas pekerjaannya dengan baik apabila mereka mempunyai motivasi yang tinggi dalam melaksanakan tugas pekerjaannya yang pada akhirnya para pegawai dapat mencapai tingkat disiplin yang tinggi.

\section{SIMPULAN DAN SARAN \\ Simpulan}

Berdasarkan hasil analisis data dan pembahasan, maka dapat ditarik simpulan yang pertama yaitu, faktor-faktor yang mempengaruhi disiplin kerja pada karyawan PT. Arta Sedana Singaraja adalah, faktor motivasi sebesar 54,877\%, faktor pendidikan dan pelatihan sebesar $20,074 \%$, faktor kepemimpinan sebesar 11,994\%, faktor kesejahteraan sebesar 8,884\%, faktor penegakan disiplin melalui hukum sebesar 4,171\%. Kedua faktor motivasi menjadi fakor yang paling dominan karena memiliki nilai varimax rotation sebesar $54,877 \%$, artinya total nilai varimax rotation dari faktor motivasi mampu menjelaskan disiplin kerja karyawan sebesar $54,877 \%$.

\section{SARAN}

Berdasarkan simpulan di atas, motivasi menjadi faktor yang paling dominan mempengaruhi disiplin kerja karyawan pada PT. Arta Sedana Singaraja. Maka saran yang dapat diajukan kepada perusahaan guna meningkatkan disiplin kerja pada karyawan yaitu; yang pertama agar karyawan termotivasi dalam bekerja hendaknya perusahaan memberikan promosi jabatan atau jenjang karir yang sesuai dengan kemampuan, prestasi, dan perilaku karyawan itu sendiri, dengan tujuan untuk menambah semangat kerja dalam mencapai bahkan melebihi target yang ditetapkan. Yang keduaa agar karyawan menjadi termotivasi dalam bekerja, hendaknya perusahaan menjaga kondisi 
lingkungan sosial, salah satunya dengan mengadakan acara keakraban guna menjalin komunikasi yang baik antar karyawan maupun dengan atasan. Komunikasi yang baik atar karyawan bertujuan untuk menghindari persepsi yang salah dan meningkatkan keharmonisan antar karyawan agar terciptanya suasana yang kondusif. Yang ketiga yaitu seluruh anggota perusahaan hendaknya menjaga kebersihan di lingkungan tempat kerja, dan merawat perlengkapan kerjanya sesuai dengan prosedur, dengan tujuan agar terciptanya rasa nyaman bagi karyawan maupun pihak didalamnya dalam bekerja serta terhindar dari kecelakaan kerja, sehingga karyawan menjadi termotivasi dalam bekerja

\section{DAFTAR PUSTAKA}

Ardana, dkk. 2012. Manajemen Sumber Daya Manusia. Yogyakarta : Graha IImu

Bangun, Wilson. 2012. Manajemen Sumber Daya Manusia. Jakarta: Erlanga

Hasibuan, Malayu. 2012. Manajemen Sumber Daya Manusia edisi Revisi. Yogyakarta: CV Masagung

Human Resource Development (HRD). 2016. Peraturan dan Sanksi Perusahaan PT. Arta Sedana Singaraja. Singaraja: PT Arta Sedana Singaraja

Lateiner, AR. 1995. Teknik Memimpin Pegawai dan Pekerja (Terjemahan Imam Soedjono). Jakarta: Aksara Baru

Nasution, Mulia. 2009. Manajemen Personalia. Jakarta: Jambatan

Rosidah dan Ambar. 2003. Manajemen Sumber Daya Manusia Konsep, Teori, dan Pengembangan dalam Konteks Organisasi Publik. Yogyakarta: Graha IImu

Siagan, Sondang P. 2009. Managemen Sumber Daya Manusia Edisi 3. Jakarta: PT Bumi Aksara.
Sinambela, Lijan Poltak. 2012. Kinerja Pegawai Teori Pengukuran Dan Implikasi. Yogyakarta: Graha IImu

Sutrisno, Edy. 2009. Manajemen Sumber Daya Manusia. Jakarta: Kencana Prenamedia

Zuriah, Nurul. 2006. Metodologi Penelitian Sosial Dan Teori - Aplikasi. Jakarta: Bumi Aksara. 